\title{
Comparative Analyses of Stomatal Size and Density among Ecotypes of Aster hispidus (Asteraceae)
}

\author{
Yoshimasa Kumekawa ${ }^{1}$, Haruki Miyata ${ }^{1}$, Kyohei Ohga ${ }^{1}$, Hiroshi Hayakawa ${ }^{1}$, Jun Yokoyama ${ }^{2}$, \\ Katsura Ito $^{1}$, Shin-Ichi Tebayashi ${ }^{1}$, Ryo Arakawa ${ }^{1}$, Tatsuya Fukuda ${ }^{{ }^{*}}$ \\ ${ }^{1}$ Graduate School of Integrated Arts and Sciences, Kochi University, Kochi, Japan; ${ }^{2}$ Faculty of Science, Yamagata University, Ya- \\ magata, Japan. \\ Email: *tfukuda@kochi-u.ac.jp
}

Received January $5^{\text {th }}, 2013$; revised February $8^{\text {th }}, 2013$; accepted February $17^{\text {th }}, 2013$

\begin{abstract}
To determine the size and the density of stomata among different environments, we conducted anatomical analyses using Aster hispidus var. hispidus (open field), As. hispidus var. leptocladus (serpentine soil), and As. hispidus var. insularis (coastal). The stomatal size was not significantly different among these ecotypes but the density of stomata in the serpentine and coastal ecotypes was significantly lower than that of As. hispidus var. hispidus, which suggests that these ecotypes have experienced selection that reduced the density of stomata for adaptation to the dry conditions of serpentine and coastal areas.
\end{abstract}

Keywords: Aster hispidus; Costal; Ecotype; Density; Guard Cell; Serpentine; Size

\section{Introduction}

Stomata control the movement of gases in and out of a leaf, make carbon dioxide available for photosynthesis, and control the loss of water from the leaf through transpiration. Gas exchange is regulated by controlling the aperture of the stomatal pore and the number of stomata that form on the epidermis. The stomatal pores that perforate leaf surfaces are among the best-characterized examples of the fundamental biological relationship between form and function [1]. The density of the stomata determines the stomatal conductance to $\mathrm{CO}_{2}$ and $\mathrm{H}_{2} \mathrm{O}$ $[2,3]$ because gaseous diffusion is regulated through turgor-mediated variation in the aperture of stomatal pores $[4,5]$. The closure of stomata under dry atmospheric or soil conditions limits $\mathrm{CO}_{2}$ diffusion from the atmosphere to chloroplasts; therefore, stomatal physiology is inextricably linked with stomatal physiology is inextricably linked to the physiology of photosynthesis [6]. As a result, the patterning of stomata on leaf surfaces is correlated strongly with hydrological conditions [7,8].

Aster hispidus Thunb. (Asteraceae) is widely distributed across China, Korea, and Japan, and is found in lowland open fields and grasslands. This species has intraspecific taxa in Japan, namely As. hispidus var. hispidus, As. hispidus var. leptocladus (Makino) Okuyama, As. hispidus var. koidzumianus (Kitam.) Okuyama, As.

${ }^{*}$ Corresponding author. hispidus var. tubulosus K. Asano ex T. Shimizu, and As. hispidus var. insularis (Makino) Mot. Ito $[9,10]$. Of these varieties, As. hispidus var. leptocladus is found in serpentine areas of central Honshu, Kyushu, and Shikoku, and As. hispidus var. insularis is restricted to coastal areas along the Pacific Ocean of western Shikoku and eastern Kyushu [9,11]. It is possible that the ecological transitions from open habitats (As. hispidus var. hispidus) to serpentine (As. hispidus var. leptocladus) or coastal conditions (As. hispidus var. insularis) has driven the evolution of stomatal patterning. The stomatal number may provide insights into evolution in terms of leaf anatomy and the response to different ecological changes. However, the extent to which the diversity of stomatal traits is linked to habitat remains unknown. The aim of this study was to characterize the anatomy of As. Hispidus var. hispidus, As. hispidus var. leptocladus, and As. hispidus var. insulari with regard to the occurrence of stomata on the abaxial leaf surface. The stomatal number changed (i.e., stomata density was reduced on the surface) as the ecotypes of As. hispidus moved into regions with distinct environments.

\section{Materials and Methods}

The samples used in this study were obtained from open (Aster hispidus var. hispidus), serpentine (As. hispidus var. leptocladus), and seashore fields (As. hispidus var. insularis) (Figure 1, Table 1). 


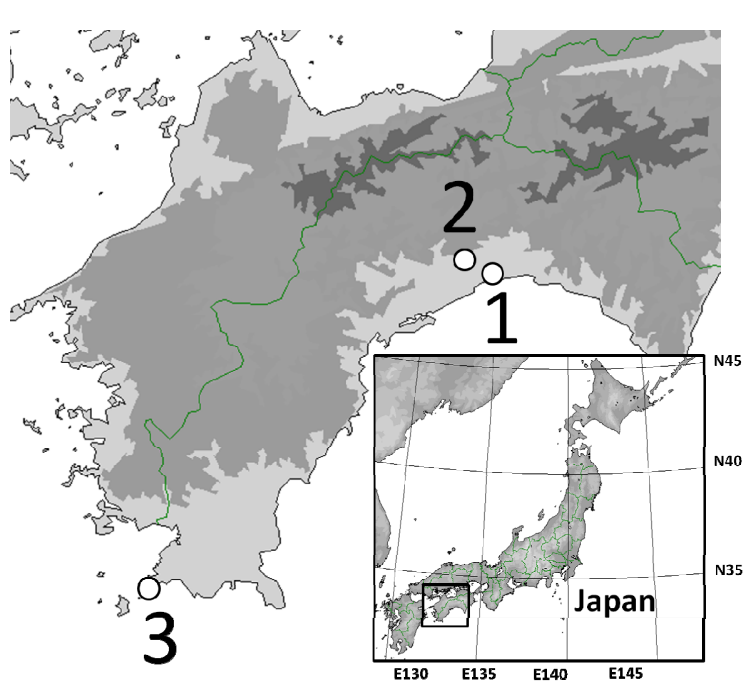

Figure 1. Sampling localities used in this study. For other abbreviations, see Table 1.

Table 1. Sampling localities used in this study.

\begin{tabular}{|c|c|c|c|c|}
\hline Species & $\begin{array}{l}\text { Sample } \\
\text { size }\end{array}$ & $\begin{array}{l}\text { Locality } \\
\text { no. }\end{array}$ & Locality & $\begin{array}{l}\text { Latitude and } \\
\text { Longitude }\end{array}$ \\
\hline $\begin{array}{c}\text { Aster } \\
\text { ispidus } \\
\text { var. } \\
\text { hispidus }\end{array}$ & 58 & 1 & $\begin{array}{c}\text { Kochi Prefecture, } \\
\text { Nankoku City, Monobe }\end{array}$ & $\begin{array}{l}33^{\circ} 33^{\prime} 12^{\prime \prime} \mathrm{N}, \\
133^{\circ} 40^{\prime} 43^{\prime \prime} \mathrm{E}\end{array}$ \\
\hline $\begin{array}{l}\text { var. } \\
\text { leptocladus }\end{array}$ & 22 & 2 & $\begin{array}{l}\text { Kochi Prefecture, } \\
\text { Kochi City, Ikku }\end{array}$ & $\begin{array}{l}33^{\circ} 35^{\prime} 40^{\prime \prime} \mathrm{N}, \\
133^{\circ} 35^{\prime} 12^{\prime \prime} \mathrm{E}\end{array}$ \\
\hline $\begin{array}{l}\text { var. } \\
\text { insularis }\end{array}$ & 15 & 3 & $\begin{array}{c}\text { Kochi Prefecture, } \\
\text { Hata-gun, } \\
\text { Otsuki-Cho Hirayama }\end{array}$ & $\begin{array}{l}32^{\circ} 47^{\prime} 15^{\prime \prime} \mathrm{N} \\
132^{\circ} 40^{\prime} 4^{\prime \prime} \mathrm{E}\end{array}$ \\
\hline
\end{tabular}

Locality no. corresponds to that given in Figure 1.

We analysed 58, 22, and 15 leaves from individuals of As. hispidus var. hispidus, As. hispidus var. leptocladus, and As. hispidus var. insularis, respectively. The middle part of a leaf blade along the midrib was examined. To identify the morphology of the guard cells and the density of the stomata, the abaxial leaf surface was replicated using Suzuki's Universal Micro-Printing (SUMP) method. Replicas of each leaf $\left(1 \mathrm{~mm}^{2}\right)$ were prepared to determine the stomatal density and to measure the guard cell size and epidermal cell size (10 cells per leaf) using cellSens standard Imaging software (Olympus Co., Tokyo) (Figure 2. Moreover we treated as an individual value the average value of the measured data. The collected data were analysed using Tukey's honestly significant difference (HSD) test to compare the characters. The numerical data were subjected to statistical analysis based on [12].

\section{Results and Discussion}

The guard cell size of Aster hispidus var. hispidus, As. hispidus var. leptocladus, and As. hispidus var. insularis was $204.31 \pm 23.55 \mu \mathrm{m}^{2}, 227.71 \pm 55.25 \mu^{2}$, and $207.49 \pm 20.24 \mu \mathrm{m}^{2}$, respectively, and there was no significant differences among them (Table 2). Moreover, the density of stomata $\left(\mathrm{N} / \mathrm{mm}^{2}\right)$ in As. hispidus var. hispidus, As. hispidus var. leptocladus, and As. hispidus var. insularis was $70.66 \pm 13.29$, $28.52 \pm 6.79$, and $33.42 \pm$ 4.09, respectively (Table 2). The stomatal density in As. hispidus var. leptocladus and As. hispidus var. insularis was significantly fewer than that of As. hispidus var. hispidus. The abaxial epidermal cell size of As. hispidus var. hispidus, As. hispidus var. leptocladus, and As. hispidus var. insularis was $883.71 \pm 239.24 \mu \mathrm{m}^{2}, 1563.65 \pm$ $475.82 \mu^{2}$, and $2012.09 \pm 319.85 \mu \mathrm{m}^{2}$, respectively (Table 2). The abaxial epidermal cell size of As. hispidus var. leptocladus and As. hispidus var. insularis was significantly smaller than that of As. hispidus var. hispidus. Thus, As. hispidus var. leptocladus and As. hispidus var. insularis showed reduced stomatal density because of increased epidermal cell size and decreased stomatal number relative to As. hispidus var. hispidus.

Stomatal control of water loss allows plants to occupy habitats with fluctuating environmental conditions. A reduction in stomatal density may have occurred in the As. hispidus complex as an adaptation to reduce the evaporation and transpiration of water. In fact, plants growing in high-salinity habitats exposed to more or less constant water stress. Aster hispidus var. insularis occurs in coastal areas on the Pacific Ocean side. To survive coastal conditions, plants have developed growth strategies such as increased water-use efficiency via $\mathrm{C}_{4^{-}}$or CAM metabolism [13], succulent growth, and extensive root systems [14]. Therefore, As. hispidus var. insularis has adapted to coastal areas by developing succulent growth and by reducing stomatal density.

Geologically unique areas are often centres of biodiversity, and thus plant speciation. Serpentine soils present a generally stressful growing environment for plants because of a number of edaphic factors such as a low $\mathrm{Ca} / \mathrm{Mg}$ ratio, low levels of essential plant nutrients, poor water retention, and high concentrations of several heavy metals [15]. In particular, high levels of nickel in the soil block a plant's ability to take in soil nutrients. In fact, plants growing on serpentine soils were found to have a low $\mathrm{Ca} / \mathrm{Mg}$ ratio and high concentrations of heavy metals [16]. Moreover, because serpentine soils are shallow and low in organic matter and clay, they also cannot hold water well [15], suggesting that this environment is similar to the dry conditions. Our results indicate that the serpentine-adapted variety As. hispidus var. leptocladus had a lower density of stomata than As. hispidus var. hispidus (Table 2). This finding suggests that this stomatal type developed for adaptation to dry environments. Similarly, [17] reported that the stomatal size and density of the serpentine ecotype of Adenophora 




Figure 2. Suzuki's Universal Micro-Printing method (SUMP) replicas. Abaxial epidermal cells of (a) Aster hispidus var. hispidus; (b) As. hispidus var. leptocladus; and (c) As. hispidus var. insularis. Arrowheads indicate stomata. Bar = $100 \mu \mathrm{m}$.

Table 2. Anatomical measurement (average \pm standard deviation) of the Aster hispidus ecotypes.

\begin{tabular}{|c|c|c|c|c|c|c|}
\hline \multirow{2}{*}{ Trait } & \multicolumn{6}{|c|}{ Aster hispidus } \\
\hline & var. hispidus & & var. leptocladus & & var. insularis & \\
\hline Guard cell size $\left(\mu m^{2}\right)$ & $204.31 \pm 23.55$ & $\mathrm{a}$ & $227.71 \pm 55.25$ & $\mathrm{~b}$ & $207.49 \pm 20.24$ & $\mathrm{ab}$ \\
\hline Stomatal density $\left(\mathrm{N} / \mathrm{mm}^{2}\right)$ & $70.66 \pm 13.29$ & $\mathrm{~b}$ & $28.52 \pm 6.79$ & a & $33.42 \pm 4.09$ & $\mathrm{a}$ \\
\hline Epidermal cell size $\left(\mu m^{2}\right)$ & $883.71 \pm 239.24$ & $\mathrm{a}$ & $1563.65 \pm 475.82$ & $\mathrm{~b}$ & $2012.09 \pm 319.85$ & c \\
\hline
\end{tabular}

Columns marked by different letters differ significantly according to the Tukey's HSD test ( $<<0.05)$.

triphylla (Thunb.) A. DC. var. japonica (Regel) H. Hara (Campanulaceae) were not significantly different from those of the normal type of this species; however, the leaf size of the serpentine ecotype was significantly smaller than that of the normal ecotype of Ad. triphylla var. japonica. Therefore, the stomatal number per leaf of the serpentine ecotype was lower than that of the normal type of this species [17], which is consistent with our results of decreased stomatal number per leaf in serpentine areas.

We analysed the size and density of stomata in the As. hispidus complex using samples adapted to different environments. However, the samples used for our analyses were collected from one population for each taxon. [18] indicated that the leaf morphology of As. hispidus var. leptocladus was significantly different among populations. Considering this report, it is possible that the size and/or density of the stomata of As. hispidus var. leptocladus and As. hispidus var. insularis may vary among populations. Therefore, additional samples from other populations will shed additional light on stomatal differentiation in different environments.

\section{Acknowledgements}

We thank Drs. O. Miura, Tunala, M. Muroi, N. Yokoyama, K. Matsuyama, S. Isomoto, Y. Yoshimi, S. Takei, N. Kakimoto, S. Inoue, R. Matsui, C. Uemoto, C. Nishimura and Y. Tsuchiya for providing additional help. This study was partly supported by a Grant-in-Aid for Scientific Research from the Ministry of Education, Science and Culture of Japan (22770084 to TF).

\section{REFERENCES}

[1] A. M. Hetherington and F. I. Woodward, "The Role of Stomata in Sensing and Driving Environmental Change," Nature, Vol. 424, No. 6951, 2003, pp. 901-908. doi:10.1038/nature01843

[2] J. Parlange and P. E. Waggoner, "Stomatal Dimensions and Resistance to Diffusion,” Plant Physiology, Vol. 46, No. 1, 1970, pp. 337-342. doi:10.1104/pp.46.2.337

[3] P. J. Franks and D. J. Beerling, "Maximum Leaf Conductance Driven by $\mathrm{CO}_{2}$ Effects on Stomatal Size and Density over Geologic Time," Proceedings of the National Academy of Sciences of the United States of America, Vol. 106, No. 23, 2009, pp. 10343-10347.

[4] K. Raschke, “Stomatal Action,” Annual Review of Plant Physiology, Vol. 26, No. 1, 1975, pp. 309-340. doi:10.1146/annurev.pp.26.060175.001521

[5] P. J. Franks and G. D. Farquhar, "The Mechanical Diversity of Stomata and Its Significance in Gas-Exchange Control,” Plant Physiology, Vol. 143, No. 1, 2007, pp. 78-87. doi:10.1104/pp.106.089367

[6] G. D. Farquhar and T. D. Sharkey, "Stomatal Conductance and Photosynthesis," Annual Review of Plant Physiology, Vol. 33, No. 1, 1982, pp. 317-345. doi:10.1146/annurev.pp.33.060182.001533

[7] K. Aasamaa, A. Sober and M. Rahi, "Leaf Anatomical Characteristics Associated with Shoot Hydraulic Conductance, Stomatal Conductance and Stomatal Sensitivity to Changes of Leaf Water Status in Temperate Deciduous Trees,” Australian Journal of Plant Physiology, Vol. 28, No. 8, 2001, pp. 765-774. doi:10.1071/PP00157

[8] P. J. Franks, P. L. Drake and D. J. Beerling, "Plasticity in Maximum Stomatal Conductance Constrained by Negative Correlation between Stomatal Size and Density: An Analysis Using Eucalyptus globulus,” Plant, Cell \& En- 
vironment, Vol. 32, No. 12, 2009, pp. 1737-1748.

[9] S. Kitamura, “Compositae (Asteraceae),” In: Y. Satake, J. Ohwi, S. Kitamura, S. Watari and T. Tominari, Eds., Wild Flowers of Japan Herbaceous Plants Vol. 3, Heibonsha, Tokyo, 1981, pp. 156-235.

[10] M. Igari, “Wild Aster \& Chrysanthemum of Japan,” Meikousha, Tokyo, 2007.

[11] Tunala, H. Hayakawa, Y. Minamiya, S. W. Gale, J. Yokoyama, R. Arakawa and T. Fukuda, "Foliar Adaptations in Aster hispidus var. insularis (Asteraceae)," Journal of Plant Studies, Vol. 1, No. 2, 2012, pp. 19-25. doi:10.5539/jps.v1n2p19

[12] R Development Core Team, "R: A Language and Environment for Statistical Computing. R Foundation for Statistical Computing,” Vienna, 2011. http://www.R-project.org/S

[13] I. E. Keeley and P. W. Rundel, "Evolution of CAM and C-4 Carbon-Concentrating Mechanisms,” International Journal of Plant Sciences, Vol. 164, No. S3, 2003, pp. S55-S77. doi:10.1086/374192

[14] A. Henry, V. R. P. Gowda, R. O. Torres, K. L. McNally and R. Serraj, "Variation in Root System Architecture and Drought Response in Rice (Oryza sativa): Phenotyping of the OryzaSNP Panel in Rainfed Lowland Fields," Field Crops Research, Vol. 120, No. 2, 2011, pp. 205-214. doi:10.1016/j.fcr.2010.10.003

[15] K. Brady, A. Kruckberg and H. Bradshaw, "Evolutionary Ecology of Plant Adaptation to Serpentine Soils,” Annual Reviews in Ecology Evolution and Systematics, Vol. 36, No. 1, 2005, pp. 243-266. doi:10.1146/annurev.ecolsys.35.021103.105730

[16] T. Mizuno, K. Horie, S. Nosaka, H. Obata and N. Mizuno, "Serpentine Plants in Hokkaido and their Chemical Characteristics,” Northeastern Naturalist, Vol. 16, No. 5, 2009, pp. 65-80. doi:10.1656/045.016.0506

[17] K. Ohga, M. Muroi, H. Hayakawa, J. Yokoyama, K. Ito, S. Tebayashi, R. Arakawa and T. Fukuda, "Morphological and Anatomical Analyses of the Serpentine Ecotype of Adenophora triphylla var. japonica (Campanulaceae)," Journal of Plant Studies, Vol. 1, No. 2, 2012, pp. 180-187. doi:10.5539/jps.v1n2p180

[18] H. Hayakawa, Tunala, Y. Minamiya, S. Gale, J. Yokoyama, K. Ito, R. Arakawa and T. Fukuda, "Comparative Study of Leaf Morphology in Aster hispidus Thunb. var. leptocladus (Makino) Okuyama (Asteraceae)," American Journal of Plant Science, Vol. 3, No. 1, 2012, pp. 110113. 